\title{
Successive Methods for the Separation of Titanium Oxide from the Black Sands of Ecuador
}

\author{
Soraya Mercedes Perez', Suhail Sharadqah ${ }^{1 *}$ \\ 1 Department of Natural Resources and Chemical Engineering, Tafila Technical University, P.O. Box 179, Tafila \\ 66110, Jordan \\ * Corresponding author's e-mail: suhail_sharadqah@yahoo.es
}

\begin{abstract}
The black sands found on certain Ecuadorian beaches present a high ilmenite contents up to 50\%. In this work, $\mathrm{TiO}_{2}$ was obtained from the black sands of Muisne beaches - Ecuador by combining the thermal, chemical and ion exchange treatments. For the thermal treatment, the raw material was smelted at temperature of $1100{ }^{\circ} \mathrm{C}$ using a basic flux. Subsequently, the chemical treatment was initiated in the presence of $\mathrm{Fe}^{0}$ metal using chemical digestion with $\mathrm{HCl}$, and the sample was purified by separating the precipitates from a series of reactions developed at different $\mathrm{pHs}$ with $\mathrm{NH}_{4} \mathrm{OH}, \mathrm{Na}_{2} \mathrm{~S}$ and $\mathrm{HCl}$. The final effluent resulting from the last $\mathrm{HCl}$ digestion was purified by ion exchange using Amberlite IRA 400 resin of strongly anionic character. The effluent is then treated in basic medium and the resulting precipitate is calcined. The recovery yield of the $\mathrm{TiO}_{2}$ pigment was $46 \%$ with $92 \%$ purity.
\end{abstract}

Keywords: ion exchange resin, muisne, Eesmeraldas - Ecuador, black sands, titanium dioxide

\section{INTRODUCTION}

Currently, the natural resources of titanium oxide in the form of Rutile, Anatase, Leucoxine, Perovskit, Sphene and Brookite are insufficient to cover the requirements of titanium oxide in different industrial applications, ranging from the elaboration of pigments, voltaic cells, food additives, in the pharmaceutical and cosmetic industry, as an antiseptic agent, etc. or as a constituent of the raw material for the recovery of metallic titanium (Valderrama et al. 2005, Perez and Sharadqah 2017).

The main ilmenite producers are: South Africa, Australia, Canada, China, India, Vietnam, Norway and Ukraine. These countries combined produced 5.3 million metric tons of ilmenite in 2009 (Gasques et al., 2014). This quantity is still insufficient to meet the growing demand for $\mathrm{TiO}_{2}$, especially for the pigment industry.

Several studies have shown that the Pacific coast has large amounts of titaniferous sand (black sands), among them Ecuadorian coasts, from which ilmenite could be obtained for the recovery of $\mathrm{TiO}_{2}$ (Martijena 1970, Trujillo and Managon 2016, Soledispa and Villacreses 1990). These sands contain variable concentrations of iron and titanium oxides, which might be bonded with other metals such as $\mathrm{Mn}, \mathrm{Mg}, \mathrm{Al}, \mathrm{V}, \mathrm{Ca}, \mathrm{Zr}$, and monazite (Dewan et al., 2010). However, in spite of the potential sources of existing in Ecuador, almost all of the $\mathrm{TiO}_{2}$ consumed is imported. Thus, the Central Bank statistics reflect that in 2015 Ecuador spent USD 1,992,350 on the imports of $\mathrm{TiO}_{2}$ (Trujillo and Managon 2016).

Generally, $\mathrm{TiO}_{2}$ recovery methods involve thermal treatments, chemical extractions, or a combination of these two methods. In some cases, the ilmenite of the black sands is concentrated beforehand by magnetic separation (Valderrama et al. 2005, Valderrama 2008, Cruz-Crespo et al. 2001, Perez and Sharadqah 2017). However, previous studies have corroborated that the magnetic treatment prior to other processes does not significantly influence the concentration of the $\mathrm{TiO}_{2}$ in the final product (Perez and Sharadqah 2017). For this reason the objectives of this work are: 
- Present a modified method of $\mathrm{TiO}_{2}$ recovery omitting the stage of magnetic concentration, applying the thermal and chemical treatments in combination with ion exchange.

- Investigate the use of this modified method using metal iron as a reducing agent in the chemical treatment, with the background that in quite high levels of yield and purity (yield $40 \%$ and $90 \%$ purity) have been obtained in the presence of metallic iron in the authors' previous work (Perez and Sharadqah 2017) and to analyze if it is possible to improve these levels by applying this modified method.

\section{MATERIALS AND METHODS}

The Esmeraldas coast presents large deposits of black sand, a raw material which could be used to obtain the $\mathrm{TiO}_{2}$. The beaches of the canton Muisne, south of the province Esmeraldas were chosen to obtain the raw material for the present study (Fig. 1).

The treatments used for the recovery of $\mathrm{TiO}_{2}$ are thermal, chemical and finally ion exchange; each of them will be explained as follows:

1. Thermal treatment. A basic flux for the melting of the sample at $1100^{\circ} \mathrm{C}$ was applied. $\mathrm{NaOH}$ is the most commercially used compound and was applied in proportion 1:2 in relation to the amount of raw material and flux. The sample resulting from the thermal treatment has been dif- ferentiated to two distinct bands: the pale gray color nucleus and the dark outer crust. The treatments were continued using the pale gray part in which the $\mathrm{TiO}_{2}$ content is higher.

2. Chemical treatment (acid digestion). Acid digestion is performed in order to separate the iron contaminants. Concentrated $\mathrm{HCl}$ was used in the pale gray fraction of the sample product of the melting because it is richer in $\mathrm{Na}_{2} \mathrm{TiO}_{3}$ and poor in iron impurities like $\mathrm{Fe}_{2} \mathrm{O}_{3}$. Figure 3 of Perez and Sharadqah 2017 work summarizes the details of the method; with the consideration that at this stage it was only experimented in the presence of metallic iron.

3. Ion exchange and calcination. An effluent which contains the iron contaminants in the form of $\mathrm{FeCl}^{-4}$ anionic complex was obtained from the acid digestion. For this reason, it was decided to choose the AMBERLITE IRA-400, which is a strongly anionic resin, to remove this complex. The AMBERLITE was activated with $9 \mathrm{~N} \mathrm{HCl}$. The optimum flow conditions were determined by analyzing the iron content of the effluent, finally adopting a system of 2 columns and flow of $1.5 \mathrm{ml} / \mathrm{min}$. After iron impurities were removed by ion exchange, $4 \% \mathrm{NH}_{4}$ (OH) was added to precipitate the amorphous titanium. This precipitate was then calcined at $900^{\circ} \mathrm{C}$, thus obtaining the purified $\mathrm{TiO}_{2}$ of rutile structures. Figure 2 shows the sequence of the combined methods employed and the principal mechanisms of chemical reactions.

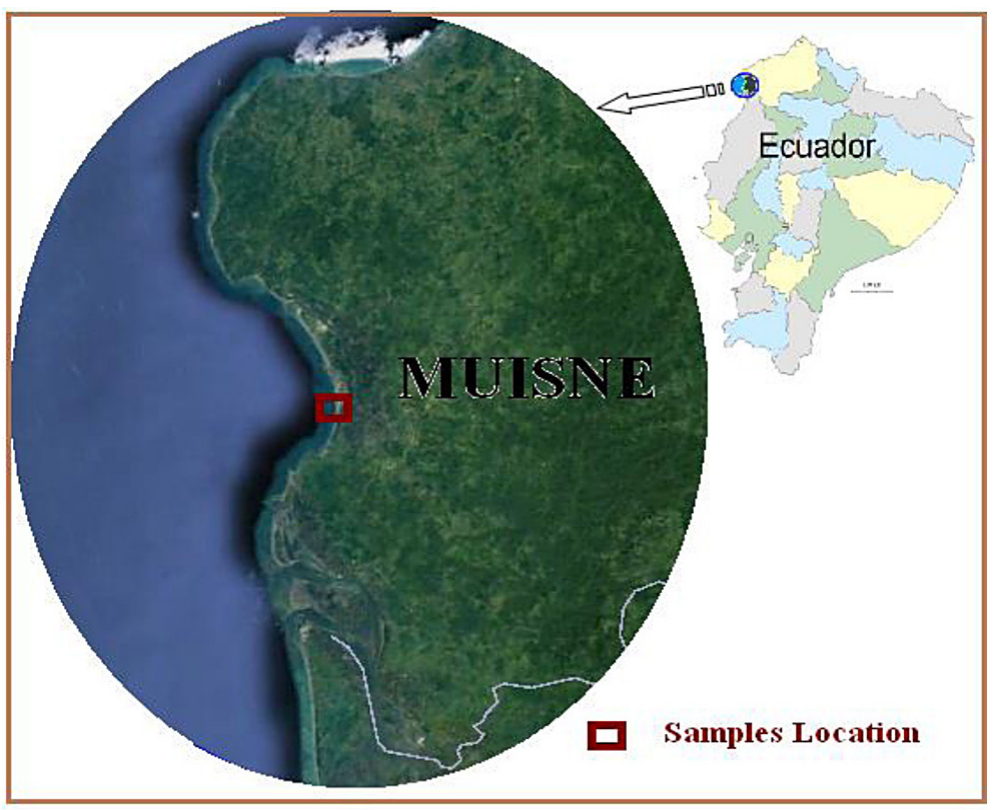

Fig. 1. Location of samples in Muisne coasts - Ecuador 
Treatment Phase

Thermal

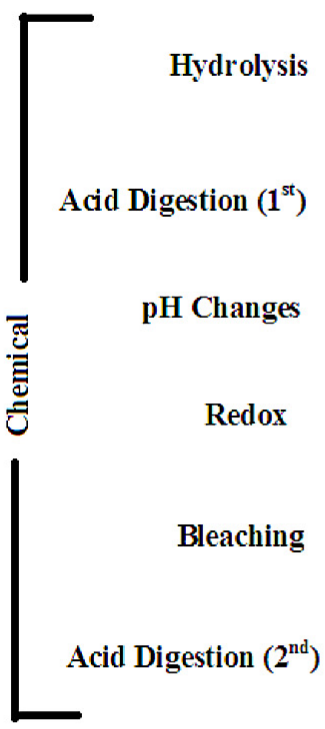

Ion Exchange

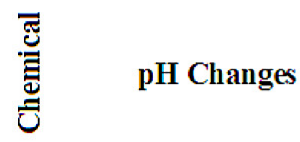

Calcination
$\mathrm{S}_{3}$

proportion 1:2 black sand-flux at $1100{ }^{\circ} \mathrm{C}$
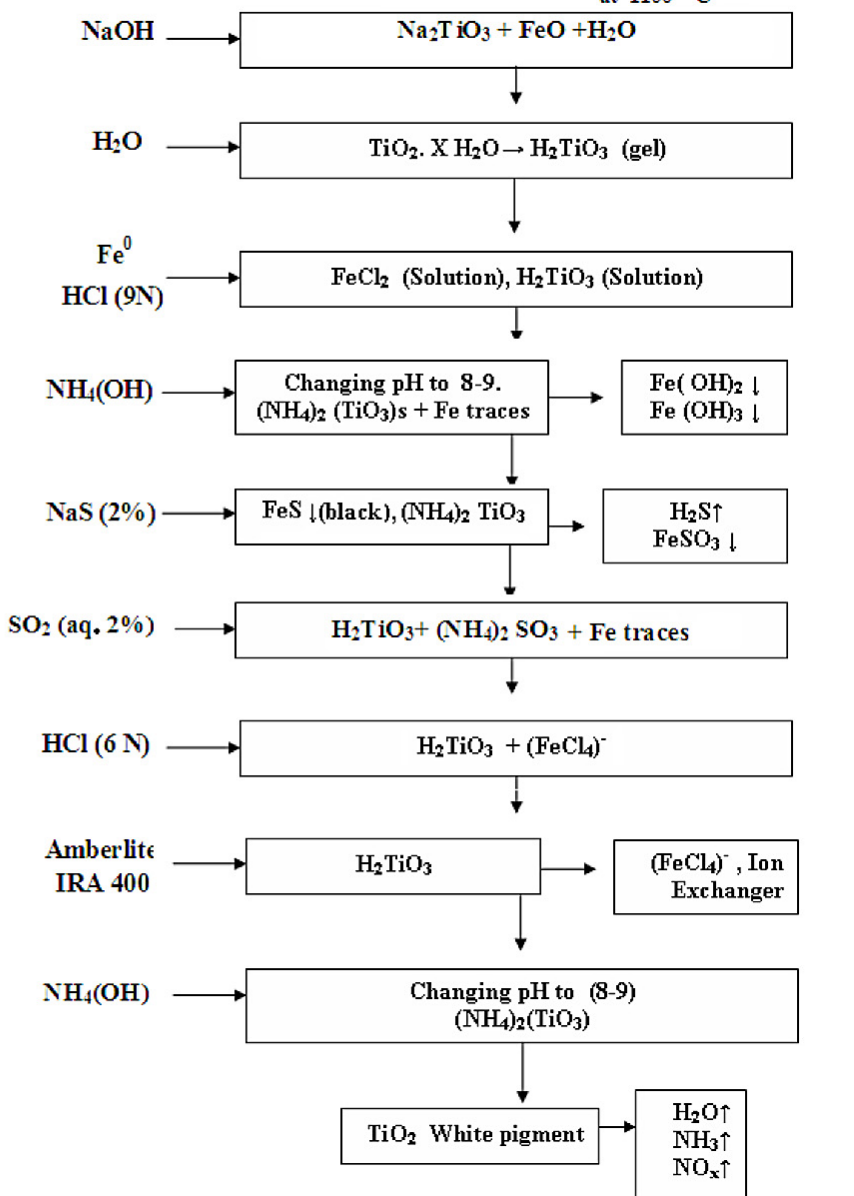

Fig. 2. The principal chemical reactions mechanisms and the experimental design sequence of the combined methods employed to $\mathrm{TiO}_{2}$ recovery

\section{RESULTS AND DISCUSSION}

\section{Row material}

The chemical analysis of different samples of black sand from Muisne beaches is presented in Figure 3. In general, it was found that the content of $\mathrm{TiO}_{2}$ in the raw material (black sands) ranges from 25 to $28 \%$. By stoichiometry, the percentage of ilmenite $\left(\mathrm{FeO} . \mathrm{TiO}_{2}\right)$ corresponding to the raw material for each sample is calculated, assuming that the total $\mathrm{TiO}_{2}$ content is of the ilmenite, the average percentage of which is around $51 \%$. Other studies in black sands in the province of Esmeraldas-Ecuador are in agreement with the data obtained in this work, (Perez and Sharadqah 2017) (Martijena 1970, Trujillo and Managon 2016). This concentration of ilmenite is quite high, but even so, it does not reach the characteristics of a concen- trate, which should reach a percentage higher than $75 \%$ (Xiong et al., 2011). The presence of ilmenite and other iron minerals such as magnetite $\left(\mathrm{Fe}_{3} \mathrm{O}_{4}\right)$ and hematite $\left(\mathrm{Fe}_{2} \mathrm{O}_{3}\right)$ are confirmed by the high iron content quantified as $\mathrm{Fe}_{2} \mathrm{O}_{3}$.

The physicochemical analyses performed in 4 samples determined an average real density of $4.79 \mathrm{~g} / \mathrm{cm}^{3}$, and an apparent density of $3.03 \mathrm{~g} / \mathrm{cm}^{3}$, as well as the particle size of $186 \mu \mathrm{m}$. The average mineralogical content calculated from the results of Figure 2 shows that $26.7 \%, 52.24 \%$, and $18.74 \%$ is $\mathrm{TiO}_{2}$, iron quantified as $\mathrm{Fe}_{2} \mathrm{O}_{3}$ and $\mathrm{SiO}_{2}$ respectively. These results are in a good agreement with the studies carried on black sand in different coasts of Esmeralda province (Trujilllo and Managon 2016, Perez and Sharadqah 2017). The sample S3 was chosen to continue the chemical treatment considering that it presents the highest percentage of ilmenite (54.1\%). 


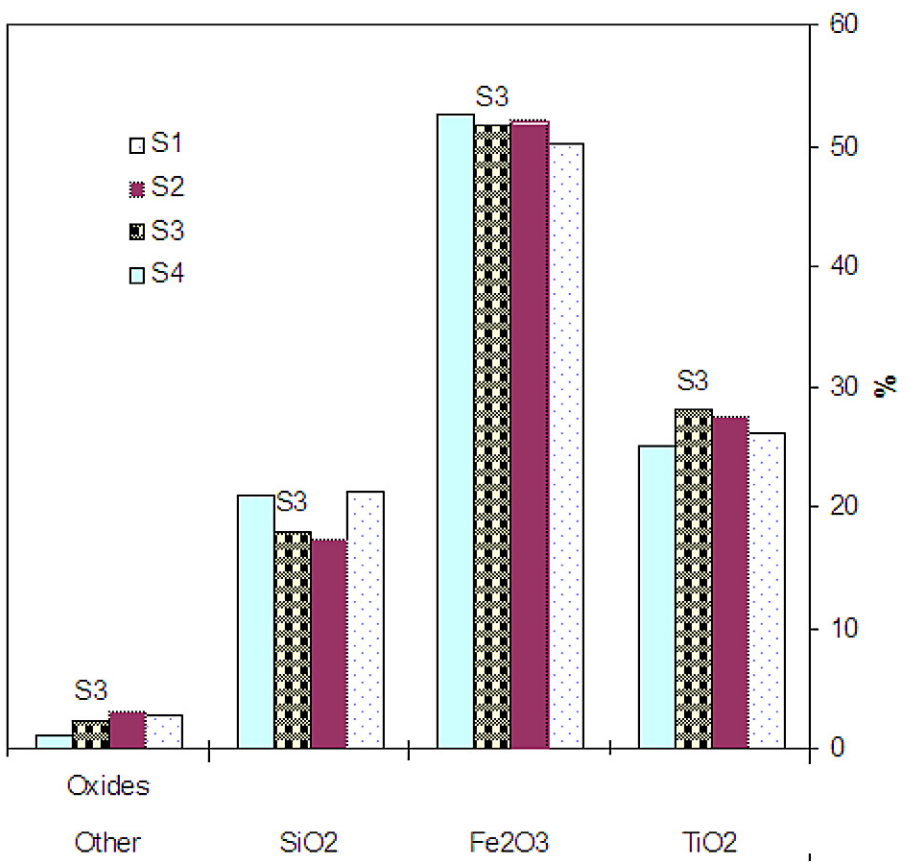

Fig. 3. Chemical analysis of four different samples (S) of black sands

\section{Thermal treatment}

The gray fraction resulting from the thermal treatment of the S3 sample was analyzed and presented a composition of $37 \%$ Iron, $30 \% \mathrm{TiO}_{2}, 28 \%$ $\mathrm{SiO}_{2}$ and about $5 \%$ of other compounds. Thermal treatment is recommended to remove impurities that can not be removed by conventional physical or mechanical treatments. The other black fraction also resulting from the thermal treatment had the following composition: $70 \%$ Iron, $22 \% \mathrm{TiO}_{2}$ and $8 \% \mathrm{SiO}_{2}$. Reaction (1a) and (1b) (Perez and Sharadqah 2017) synthesizes the possible components resulting from this step.

$$
\begin{array}{r}
\mathrm{FeOTiO}_{2}+2 \mathrm{NaOH} \stackrel{1100^{\circ} \mathrm{C}}{\rightarrow} \mathrm{Na}_{2} \mathrm{TiO}_{3}+\mathrm{FeO}+\mathrm{H}_{2} \mathrm{O} \\
2 \mathrm{FeOTHO}_{2}+4 \mathrm{NaOH}+1 / 2 \mathrm{O}_{2} \longrightarrow{ }^{1100^{\circ} \mathrm{C}} \rightarrow \\
+\mathrm{Na}_{2} \mathrm{TiO}_{3}+ \\
+\mathrm{Fe}_{2} \mathrm{O}_{3}+2 \mathrm{H}_{2} \mathrm{O}
\end{array}
$$

\section{Chemical treatment and ion exchange}

The gray fraction resulting from the smelting process is hydrolyzed with water to obtain the hydrated titanium dioxide $\left(\mathrm{TiO}_{2} \cdot \mathrm{XH}_{2} \mathrm{O}\right)$, which has a gelatinous aspect and a chemical structure similar to the silicon compounds, because it belongs to the same family (Ayres 2017). The major reactions of this stage are the following:

$$
\mathrm{Na}_{2} \cdot \mathrm{TiO}_{3}+\mathrm{H}_{2} \mathrm{O} \rightarrow \mathrm{TiO}_{2}(\mathrm{aq} .)+2 \mathrm{NaOH}
$$

$$
\mathrm{TiO}_{2}(\text { aq. }) \stackrel{\mathrm{H} 2 \mathrm{O}}{\rightarrow} \mathrm{TiO}_{2} \cdot \mathrm{xH}_{2} \mathrm{O} \rightarrow x \mathrm{H}_{2} \mathrm{TiO}_{3}(\text { gel })
$$

Subsequently, the acid digestion was performed in the presence of iron as the reducing agent of the titanate obtained in the previous phase with the antecedent in the presence of which better yield levels of this metal are obtained (Martijena 1970).

The above-mentioned product is treated in a basic medium and bleached with sodium sulfide as indicated by the procedure detailed in Perez and Sharadqah 2017.

The last step of the chemical treatment is a second acid digestion with $\mathrm{HCl}$ in which the iron traces participate in a series of reactions in contact with the chloride ions $\left(\mathrm{Cl}^{-}\right)$. The formation of the anionic $\mathrm{FeCl}^{4-}$ complex occurs due to the following consecutive chemical reaction mechanisms (Ponn 2006):

$$
\begin{gathered}
\mathrm{FeCl}_{3}+\mathrm{H}_{2} \mathrm{O} \rightarrow \mathrm{Fe}^{3+}+3 \mathrm{Cl}^{-} \\
\mathrm{Fe}^{3+}+6 \mathrm{H}_{2} \mathrm{O} \rightarrow\left[\mathrm{Fe}\left(\mathrm{H}_{2} \mathrm{O}\right)_{6}\right]^{3+}(\mathrm{aq} .) \\
{\left[\mathrm{Fe}\left(\mathrm{H}_{2} \mathrm{O}\right)_{6}\right]^{3+}(\mathrm{aq} .)+4 \mathrm{HCl} \rightarrow} \\
\rightarrow \mathrm{Fe}\left(\mathrm{H}_{2} \mathrm{O}\right)_{2} \mathrm{Cl}_{4}{ }^{-}+4 \mathrm{H}_{3} \mathrm{O}^{+} \\
\mathrm{Fe}\left(\mathrm{H}_{2} \mathrm{O}\right)_{2} \mathrm{Cl}_{4}{ }^{-}+2 \mathrm{H}^{2+} \rightarrow \\
\rightarrow \mathrm{FeCl}_{4}{ }^{-}(\mathrm{aq} .)+2 \mathrm{H}_{3} \mathrm{O}^{+}
\end{gathered}
$$

The $\mathrm{FeCl}^{4-}$ anionic complex is retained in the Amberlite Ira-400 resin, which is evidenced with a clear yellow to transparent color change of the exchange column effluent. The degree of iron reten- 
tion in the column was quite high, since the chemical analysis of the effluent before and after the ion exchange was $3522 \mathrm{ppm}$ and $41 \mathrm{ppm} \mathrm{Fe}_{2} \mathrm{O}_{3}$, respectively. This result is in a good agreement with previous works (Perez and Sharadqah 2017).

From the ion exchange, an iron-free solution is obtained, which is brought to the $\mathrm{pH}$ between 8 and 9 in order to precipitate $\mathrm{TiO}_{2} \cdot \mathrm{XH}_{2} \mathrm{O}$ in this medium. The precipitate is a white solid that is subsequently subjected to calcination at a temperature of $900^{\circ} \mathrm{C}$ to reach rutile structures. The purity of $\mathrm{TiO}_{2}$ after this calcination stage is $92 \%$. The obtained yield is $46 \%$ of all the titanium content in the raw material. This recovery level is higher than what was achieved in other studies (Perez and Sharadqah 2017, Trujillo and Managon 2016). Taking into the account that this methodology just considers one portion of the complex resulted from the smelting process, the results become more satisfactory.

The percentage of the recovered titanium in this study is slightly higher than what achieved by Perez and Sharadqah (2017); however, in that study, the authors applied more treatments and longer procedure. This was essentially due to poor efficiency of magnetic separation in that study.

\section{CONCLUSIONS}

1. The composition of the black sands of Muisne were basically ilmenite, iron oxide, quartz and various types of silicates, such as pyroxene, olivine, leucoxene, amphiboles, epidote, zircon and cinnabar.

2. The presence of the basic $\mathrm{NaOH}$ flux in a 2:1 ratio in the sample melted at $1100^{\circ} \mathrm{C}$ actually plays an important role in the first stage of separation of the iron impurities from the ilmenite.

3. The combination of the thermal treatment with acid digestion in the presence of metallic iron and subsequent ionic exchange, reflects a remarkable improvement in relation to the previous methods that additionally carry magnetic concentration. This means that the magnetic separation is not really relevant to the recovery of titanium and the application of this combined method achieves better levels of purity and yield of $\mathrm{TiO}_{2}\left(92 \%\right.$ purity and $\left.46 \% \mathrm{TiO}_{2}\right)$.

4. The high retention capacity of the iron complex by Amberlite Ira 400 resin is $99 \%$. This facilitates achieving high purity levels of $92 \%$ of the $\mathrm{TiO}_{2}$ pigment.

\section{REFERENCES}

1. Ayres G., 2017. Analisis Quimico Cuantitativo. Castillo Editorial, pp. 248.

2. Cruz-Crespo A., Gomez-Rodriguez L., Perdomo-Gonzales L., Quintana-Puchol R., 2001. Las arenas negras de Mejias: nueva fuente para la obtencion de consumibles para la soldadura por arco electrico. Journal Mineria y Geologia, 18(2) (on line).

3. Dewan M. and Zhang G., 2010. Carbothermal reduction of a primary ilmenite concentrate in different gas atmospheres. Metallurgical and Materials Transactions B: Process Metallurgy and Materials Processing Science, 41 (1), 182-192.

4. Gasquez M., Bolivar J., Garcia-Tenorio R., Vaca F., 2014. A review of the production cycle of titanium dioxide pigment. Materials Sciences and Applications, 5, 441-458.

5. Martijena A., 1970. Posibilidades para la industria siderurgica en los paises de menor desarrollo relativo III. Ecuador. Naciones Unidas, Consejo Economico y Social. Comision Economica para America Latina. E/CN.12/855. 24 de Abril.

6. Perez S. and Sharadqah S., 2017. Recovery of $\mathrm{TiO}_{2}$ from titaniferous sand of Esmeraldas Ecuador, using ion exchange resins. Journal of Natural Sciences Research, 7(6), 80-92.

7. Ponn S., 2006. Decolourization of hydrochloric acid. Department of Chemical Engineering, Lund Institute of Technology, 1-4.

8. Soledispa B. and Villacreses J., 1990. Estudio Composicional de las arenas ferrotitaniferas del sector comprendido entre el Estero Data de Posorja y el Monasterio de Santa Teresa, Provincia de Guayas Ecuador. INOCAR, Acta Oceanografica del Pacifico.

9. Trujillo D. and Managon L., 2016. Titanium dioxide recovery from ilmenite contained in ferrotitaniferous sands from Mompiche Ecuador. Journal of Geological Resource and Engineering, 4, 175-183.

10. Valderrama L., Poblete R., Contreras C., 2005. Caracterizacion y Concentracion de Muestras de Arenas de Caldera, Region Atacama. Revista de la Facultad de Ingenieria, Universidad de Atacama, 2005, 19, 38-44.

11. Valderrama L., 2008. Concentracion de minerales de titanio contenidos en las arenas de playas de la region de Atacama-Chile. IDITEC - Universidad de Atacama-Chile. On Line:www2.ifrn.edu.br/ojs/ index.php/HOLOS/article/viewFile/152/140.

12. Xiong X., Zhi Y., Hongyong O., 2011. Study on Character of Ilmenite Modified by Thermal Treatment". Advanced Materials Research, 284(6), 2090-2093. 